\title{
Changes in activity during storage and characteristics of superoxide dismutase from hen eggs (Gallus gallus domesticus)
}

\author{
Jacek Wawrzykowski • Marta Kankofer
}

Received: 6 October 2010/Revised: 14 December 2010/Accepted: 20 December 2010/Published online: 7 January 2011

(C) The Author(s) 2011. This article is published with open access at Springerlink.com

\begin{abstract}
Hen eggs are one of the most popular food stuffs. Moreover, they can be the source of not only nutrients but also factors of biological origin, which may be used for food preservation and food additives. The aim of the study was to determine and describe the activity of superoxide dismutase isoforms (SOD; EC 1.15.1.1) in hen eggs (Gallus gallus domesticus). Our electrophoretic studies confirmed the presence of SOD isoenzyme bands with molecular weight of $14-15$ and $50-70 \mathrm{kDa}$ in egg yolk. By contrast, in egg white, we confirmed the presence of a protein with molecular weight of 13-14 and 50-55 kDa. Zymografic pattern confirmed the activity of SOD isoforms of the enzyme present in the egg yolk; however, it did not confirm enzyme activity in egg white (at the level of error of the used method). Study has also shown SOD activity during storage at $4{ }^{\circ} \mathrm{C}$ for 9 days in egg yolk and egg white. In start time, SOD activity in egg yolk is clearly different from a small activity in the protein (respectively, $90.5 \pm 22.2$ and $7.9 \pm 3.9 \mathrm{U} \mathrm{g}^{-1}$ ). It did not change during 6 days storage but between 6 th and 9 th day, it decreased significantly in egg yolk while remained low but unchanged in egg white. Present study confirmed the presence of SOD and its activity in hen egg yolk.
\end{abstract}

Keywords Hen eggs · Egg storage .

Superoxide dismutase $\cdot$ SOD

J. Wawrzykowski $(\bowtie) \cdot$ M. Kankofer

Department of Animal Biochemistry and Physiology,

Faculty of Veterinary Medicine, University of Life Sciences,

Akademicka 12, 20-033 Lublin, Poland

e-mail: jacek.wawrzykowski@up.lublin.pl

\author{
Abbreviations \\ SOD \\ Superoxide dismutase \\ U Unit of SOD activity, described \\ in "Material and methods"
}

\section{Introduction}

Hen eggs are important food product. They can be consumed unprocessed, processed, or as components of other food products [1]. They provide with high-quality nutritive proteins. It is known that majority of these proteins come from blood, but some may be produced locally [2].

Eggs are often used as coagulants, reducing the surface tension, emulsifying and foaming agents, also fit the nutritional value and taste of food [3, 4].

Many diseases associated with impaired intracellular redox potential associated with the presence of ROS were described $[6,8]$. Free radical reactions are responsible for the changes including ischemic, degenerative, or necrotic processes [9].

To prevent the destruction caused by uncontrolled reactions of ROS, living cells produce antioxidant protection [10]. It is composed of metal proteins, antioxidants such as vitamin $\mathrm{C}$ and $\mathrm{E}$ and specialized antioxidant enzymes [7].

Superoxide dismutase (SOD) belongs to the group of antioxidant enzymes, described already in 1938. They catalyze the reaction of conversion of superoxide anion to hydrogen peroxide. SOD is hydrophobic proteins of about 15-16 kDa depending on isoforms, which contains metal ions in the active center: copper and zinc, manganese, iron or nickel [11-13]. 
The eukaryotic form of $\mathrm{Cu} / \mathrm{Zn}$ SOD is present in the cytoplasm and Mn SOD in the mitochondria, while in prokaryotic cells, the presence of $\mathrm{Cu} / \mathrm{Zn} \mathrm{SOD}, \mathrm{Mn}$ SOD, $\mathrm{Fe}$ SOD, and SOD Ni was detected [14]. In chicken erythrocytes, the presence of isozymes of $\mathrm{Cu} / \mathrm{Zn} \mathrm{SOD}$ with molecular mass of $30-31$ and $15 \mathrm{kDa}$ was confirmed $[15,16]$. Mann and Mann described a protein similar to extracellular SOD with molecular mass of $31-37 \mathrm{kDa}$ in chicken yolk plasma [2].

ROS processes occurring in food lead to a reduction in its durability and quality. Therefore, the need to reduce the ROS content in food products through appropriate additives is advisable [17]. For this purpose, synthetic antioxidants such as butylated hydroxyanisole (BHA) and butylated hydroxytoluene (BHT) are used as substances, which prolong the durability of the products. But they are not inert substances for consumers. Results of experiments confirm their negative impact on the human body $[18,19]$. Looking for natural substances that can replace synthetic antioxidants is inevitable [17]. Many substances with antioxidant properties were already isolated from food products [20]. Such properties exhibit soy protein hydrolysates [21], milk protein hydrolysates, whole egg protein hydrolysates [22, 23], and egg yolk hydrolysates [24].

It is also important to monitor ROS content that could be formed during processing and subsequent storage. Due to the perishable nature of the ROS, their determination in foods is done by use of indirect methods. It is constant searching for new, specific markers of oxidative changes in food products $[6,25,26]$.

In this paper, efforts have been made to describe the characteristics of SOD derived from egg white and egg yolk as well as changes in enzyme activity as a marker of oxidative processes occurring during storage of hen eggs (Gallus gallus domesticus).

\section{Materials and methods}

Unfertilized eggs obtained from local organic farm (Obroki, Poland) were broken, and the yolk was separated from the egg white. Egg yolk and egg white were homogenized separately and divided into 8 portions, each for $2 \mathrm{~cm}^{3}$. Probes 1 and 2 were analyzed immediately, 3 and 4 after 3 days, 5 and 6 after 6 days, and 7, 8 after 9 days stored in $4{ }^{\circ} \mathrm{C}$ in dark.

\section{Determination of activity of the SOD}

The determination of SOD was performed using the method of inhibition of epinephrine auto-oxidation in alkaline medium and the measurement of the absorbance of

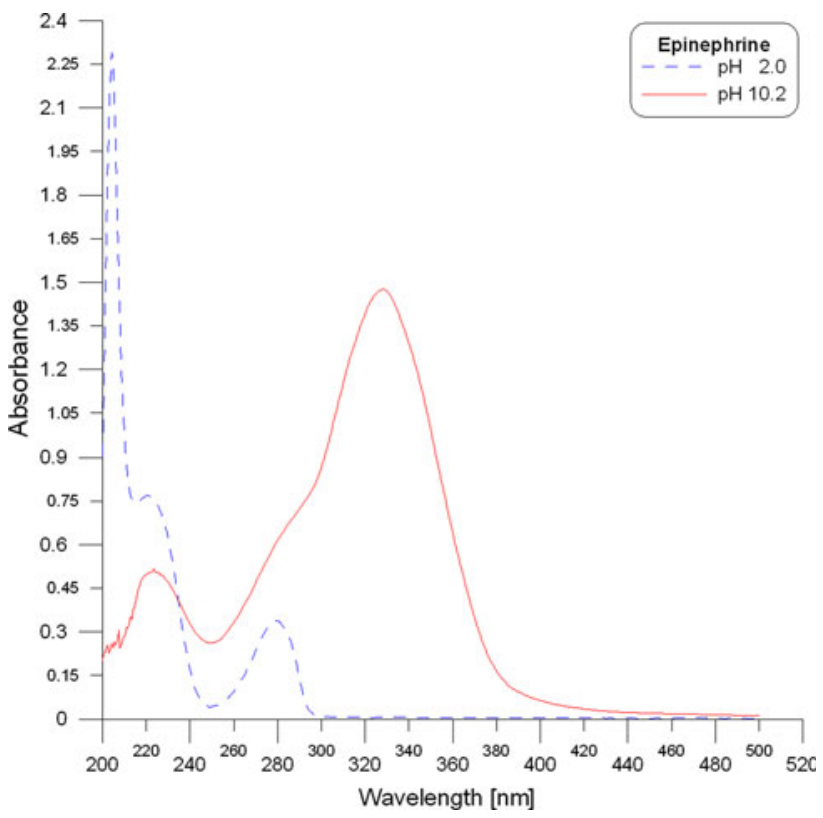

Fig. 1 Wavescan a product of auto-oxidation of epinephrine in alkaline solution

the resulting product at $340 \mathrm{~nm}$ (Fig. 1) [27, 28]. The method was adapted and optimized to conditions in eggs. The time of measured reaction was determined experimentally at $300 \mathrm{~s}$ (5 min) (Fig. 2). Variation of absorbance was calculated by the difference between the absorbance at the starting time and the absorbance after $300 \mathrm{~s}$. The increment in absorbance was then calculated into unit of SOD activity (U), where one-unit of SOD activity was

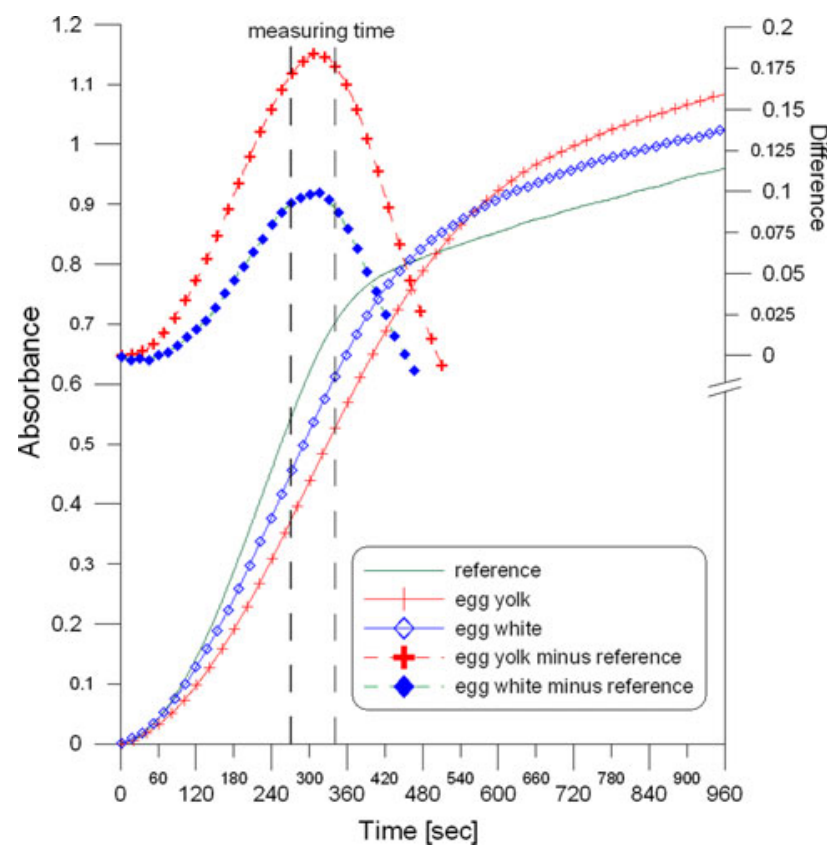

Fig. 2 Difference of the inhibition of the auto-oxidation of epinephrine in egg yolk sample, egg white sample, and control sample 
equivalent to the quantity of SOD that caused a $50 \%$ inhibition of the auto-oxidation of epinephrine.

Egg yolk samples were homogenized with $3.2 \mathrm{~cm}^{3}$ ethanol-chloroform mixture (3:5) and $0.8 \mathrm{~cm}^{3} \mathrm{NaCl}$ $(0.9 \%)$, twice centrifuged $(1,450 \mathrm{~g}, 15 \mathrm{~min})$, and upper layer was collected for further determinations.

Egg white samples were homogenized with $1.6 \mathrm{~cm}^{3}$ ethanol-chloroform mixture (3:5) and $0.4 \mathrm{~cm}^{3} \mathrm{NaCl}$ $(0.9 \%)$, twice centrifuged $(1,450 \mathrm{~g}, 15 \mathrm{~min})$, and upper layer was collected for further determinations.

$0.1 \mathrm{~cm}^{3}$ sample, $1.8 \mathrm{~cm}^{3}$ buffer $(0.05 \mathrm{M}$ carbonate buffer, $\mathrm{pH} 10.2)$, and $0.1 \mathrm{~cm}^{3}$ epinephrine $\left(18 \mathrm{mg} / 10 \mathrm{~cm}^{3}\right.$ $0.1 \mathrm{M} \mathrm{HCl}$ ) were added to the spectrophotometric cuvette. Immediately after epinephrine was added, and $300 \mathrm{~s}$ later absorbance was measured at $340 \mathrm{~nm}$. Changes in absorbance were compared with controls where enzyme was replaced by $\mathrm{NaCl}$.

The SOD activity was expressed as value of $U$ per $g$ of extracted protein $\left(\mathrm{U} \mathrm{g}^{-1}\right)$.

\section{Protein determination}

Protein content in the samples was determined according to the method based on the biuret reaction using a commercial colorimetric kit (Cormay, Poland) [25].

\section{SDS-PAGE Electrophoresis}

The SOD extracted form egg yolk and egg white was analyzed by sodium dodecyl sulfate polyacrylamide gel electrophoresis (SDS-PAGE) [29] on 10\% polyacrylamide gels using Mighty Small SE 250 (Hoefer, Pharmacia, Uppsala, Sweden). The running buffer was $0.025 \mathrm{M}$ Tris/glycine $\mathrm{pH}$ 8.3. The amount of protein loaded per each well was the same and amounted $10 \mu \mathrm{g}$. The samples were mixed with a $2 \times$ sample buffer without reducing agent. Constant voltage of $100 \mathrm{~V}$ was used. After electrophoresis, protein fractions were stained with a $0.125 \%$ solution of Coomassie brilliant blue R-250 (Merck, Warszawa, Poland) and compared with protein size marker (Fermentas, USA, respectively, 10, 15, $25,35,40,50,70,100,140$, and $260 \mathrm{kDa})$. The gels were scanned on an imagining densitometer BioRad (Ivrysur-Siene, France) and the molecular weight and relative quantities estimated with the BiorRad Quantity One 4.1 software (Ivry-sur-Siene, France).

Positive staining after gel electrophoresis was performed to confirm the presence of SOD [30]. Conditions for separation were the same as previously described. After electrophoresis, the gels were washed in $2.5 \%$ Triton X-100 for $15 \mathrm{~min}$. Then washed again in distilled water for 15 min. For the determination of SOD activity, the gels were incubated in solution containing $2 \mathrm{mmol}$ dianisidine, $0.1 \mathrm{~mol}$ riboflavin in $10 \mathrm{mmol}$ potassium phosphate buffer $\mathrm{pH} 7.2$ for $1 \mathrm{~h}$ at room temp. Then, after rinse in distilled water, the gels were illuminated for $10 \mathrm{~min}$. Brown bands against pale yellow background were considered as SOD. The inhibition studies with cyanide were performed using $1.2 \mathrm{mmol} / \mathrm{l} \mathrm{KCN}$. The gels were scanned on an imagining densitometer BioRad (Ivry-sur-Siene, France).

\section{SOD wavescan}

SOD wavescan was measured from 200 to $700 \mathrm{~nm}$ on Ultrospec 2000 (Pharmacia, Uppsala, Sweden) spectrophotometer with a BioRad Quantity One (Pharmacia, Uppsala, Sweden) computer software.

\section{Statistical analysis}

The results of spectrophotometric determinations in triplicate were subjected to statistical analysis by use of Tukey test [31] and by QI Macros Statistical Process Control Software (KnowWare International, Inc., USA) for Microsoft Excel (Microsoft, USA).

\section{Results}

The modification of the method described by Sun and Zigman [27] for SOD activity was made in order to adapt it to biological material obtained from eggs. Based on experimental data (Fig. 2), the optimal time of the measurement was set to $300 \mathrm{~s}$ (5 min).

Maximum absorbance at $450-470 \mathrm{~nm}$ wave length in the spectra of SOD extracted from white and egg yolk (Fig. 3) was shown, which confirmed the presence of $\mathrm{Mn}$ ions in enzymatic protein, but not confirmed by electrophoresis (Fig. 4) [32-34].

SDS-PAGE analysis of SOD extracted from egg yolk and egg white is shown in Fig. 4a, c. The relative content of proteins in the extract obtained from egg yolk is $73 \%$ proteins with a mass $14-15 \mathrm{kDa}$ and $8 \%$ proteins with a mass $50-70 \mathrm{kDa}$. In the extract obtained from the egg white, $15 \%$ proteins with a mass $13-14 \mathrm{kDa}$ and $78 \%$ for proteins with a mass $50-55 \mathrm{kDa}$ are observed.

In gels stained positively for SOD activity, extracts derived from chicken egg yolk show a protein band with a mass 14-15 and 50-70 kDa. The protein extract from the egg white does not exhibit any SOD activity by the method of measurement [30] (Fig. 4d, e).

The changes observed in SOD activity during storage of eggs are shown in Table 1. Changes in enzyme activity in 


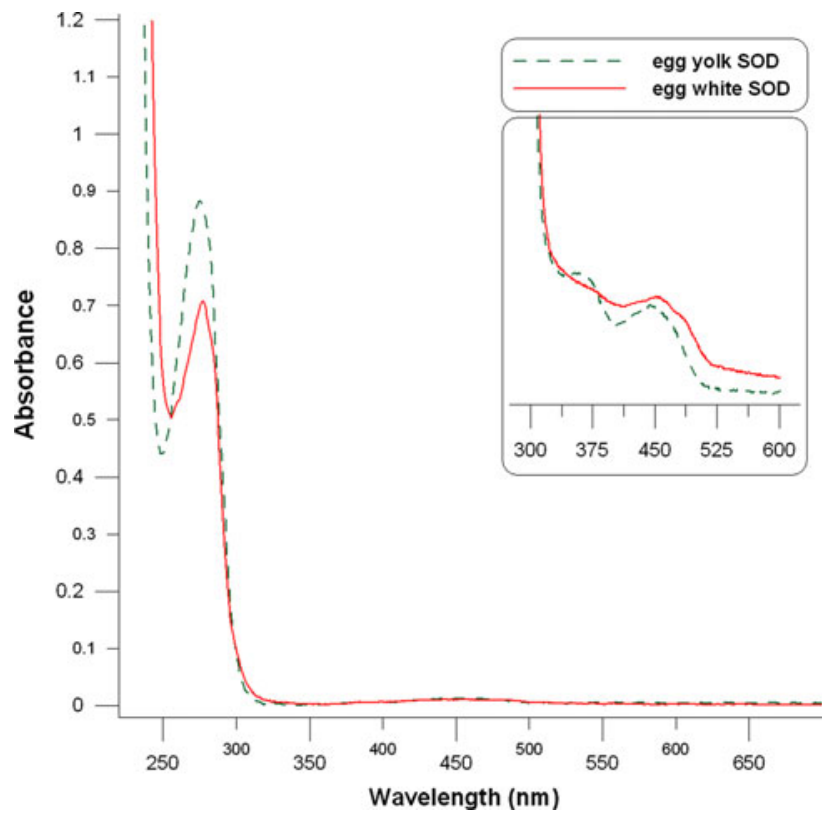

Fig. 3 SOD from egg yolk and egg white wavescan, approximately $10 \mathrm{mg} / \mathrm{cm}^{3}$ of protein contents

chicken egg white can be found at the level of error of method. While significantly, lower values (at $p<0.15$ ) were demonstrated only for SOD activity in egg yolk after 9 days of storage compared to the previous measurements.

\section{Discussion}

In this paper, SOD was extracted and partly purified from hen egg yolk and white as well as its molecular weight was determined. Enzyme activity was measured immediately after breaking the eggs and after storage at $4{ }^{\circ} \mathrm{C}$ for 3,6 , and 9 days. During the experiment, SOD activity in the extract from chicken white egg was shown at the level of detection of the method used, throughout the duration of the experiment. Small but significant decrease was also demonstrated in SOD activity after 9 days storage of egg yolk samples.

Mann \& Mann identified 119 proteins in hen egg yolk by use of $1 \mathrm{D}$ electrophoresis, LC-MS/MS, and $\mathrm{MS}^{3}$. Out of this number, 86 fractions were described for the first time. Majority of detected fractions were present in both yolk and white but in different concentrations [2].

Among different proteins, fractions similar to extracellular SOD, plasma glutathione peroxidase as well as thioredoxin, protein similar to peroxiredoxin 4 , and $121-\mathrm{kDa}$ protein similar to ceruloplasmin were detected. This confirmed that antioxidative enzymatic defense is present in egg yolk.

Froman and Thurston [35] described the presence of at least seven proteins exhibiting SOD activity in erythrocytes and semen of chicken by use of the 1D electrophoresis. However, proteins obtained in the present study from the extracts of egg yolk confirmed the presence of fractions of molecular mass of $14-15 \mathrm{kDa}$, which corresponds to SOD
Fig. 4 SDS-PAGE, SOD extracted form egg white $a$, molecular weight markers, the description in the text $b$, SOD extracted form egg yolk $c$, activity of SOD extracted form egg yolk $d$, activity of SOD extracted form egg white $e$, on $d$ and $e$ yellow background was removed by computer software

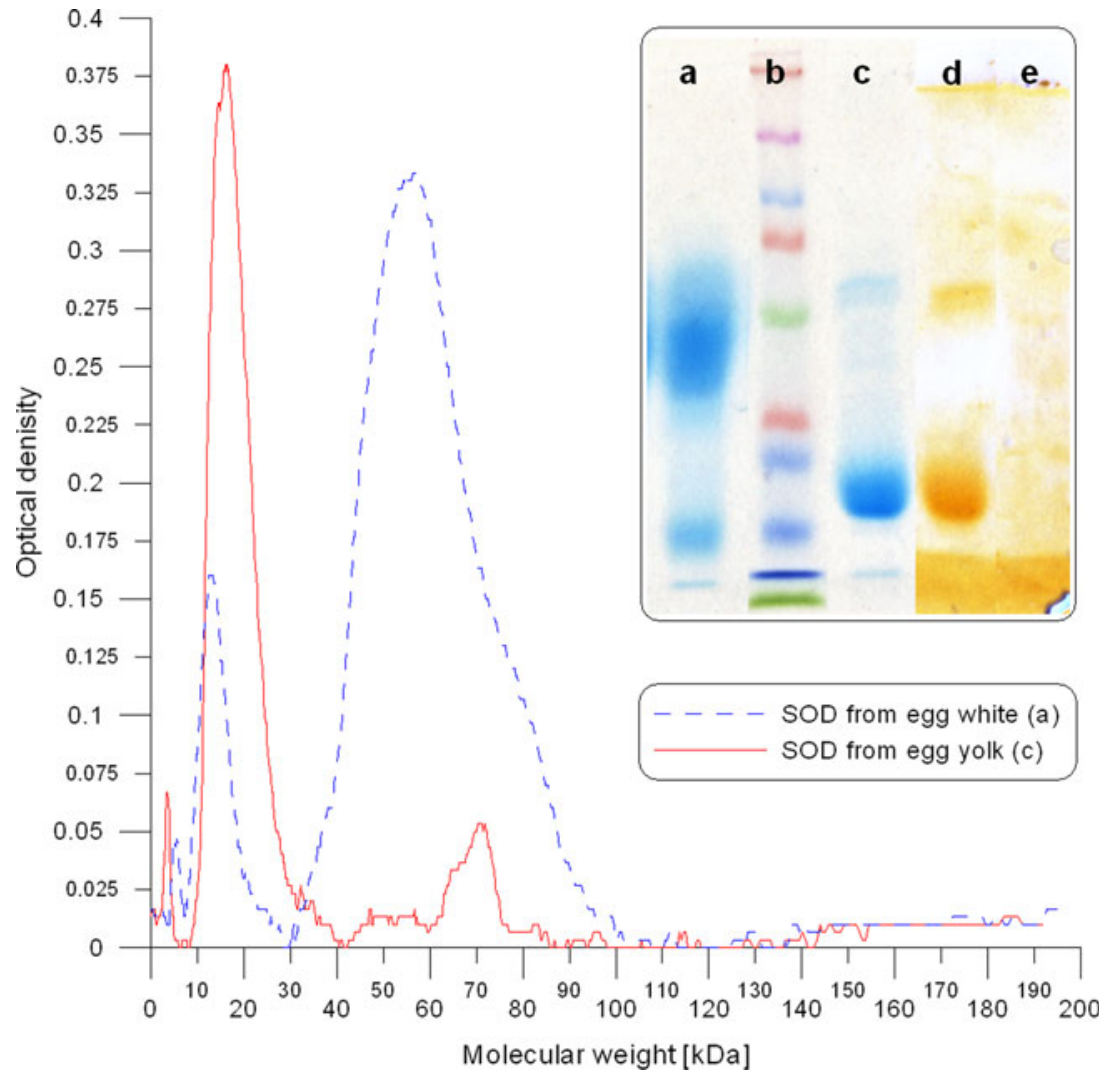


Table 1 SOD activity $\left(\mathrm{U} \mathrm{g}^{-1}\right)$ in egg yolk and egg white during storage time

\begin{tabular}{lccrc}
\hline & \multicolumn{3}{l}{ Storage time (days) } \\
\cline { 2 - 5 } & 0 & \multicolumn{1}{l}{3} & \multicolumn{1}{l}{6} \\
\hline Egg yolk & $90.5 \pm 22.2^{\mathrm{a}}$ & $97.3 \pm 25.5^{\mathrm{a}}$ & $102.7 \pm 23.7^{\mathrm{a}}$ & $79.5 \pm 13.0^{\mathrm{b}}$ \\
Egg & $7.9 \pm 3.9^{\mathrm{d}}$ & $14.4 \pm 10.1^{\mathrm{d}}$ & $32.7 \pm 10.1^{\mathrm{d}}$ & $9.8 \pm 11.4^{\mathrm{d}}$ \\
white & & & & \\
\hline
\end{tabular}

Different letter denote means differ significantly $(p<0.15)$

containing $\mathrm{Cu}$ and $\mathrm{Zn}$, isolated from chicken erythrocytes as described earlier by Aydemìr and Tarhan by the Sephadex G-100 gel column filtration and 1D SDSelectrophoresis [15] and Schininå et al. who used isoelectrofocussing and mass spectra analysis for molecular mass determination [5, 16]. This band is also similar to SOD from chicken liver reported by Öztürk-Ürek and Tarhan; they separated proteins by the Sephadex G-75 gel column filtration and determined molecular mass by SDS electrophoresis [36].

Spectrophotometric scanning (Fig. 3) confirmed the presence of $\mathrm{Mn}$ in obtained extract suggesting the origin of extracted SOD from mitochondria. The presence of Mn SOD derived from mitochondria was confirmed as a tetrameric form with molecular masses of $110-140 \mathrm{kDa}$, do not confirmed by electrophoresis. The identified proteins with a mass 50-70 kDa are not described yet as a form of SOD.

Raikos et al. [1] identified a lysozyme and ovalbumin in the egg white with masses similar to those described in this work (respectively, 13-14 and 50-55 kDa). These bands, however, did not show SOD activity by use of zymography (at the level of error of the method).

To conclude, present study confirmed the presence of SOD and its activity in hen egg yolk. The confirmation of the presence of SOD in egg white requires an additional analysis.

Slight variations in SOD activity of egg yolk during storage may indicate that it can be used as a source of enzymes. Unfortunately, the low activity of the enzyme obtained disqualifies its wider use.

Acknowledgments We are grateful to R. Wawrzykowska for help with collecting eggs and R. Chilczuk for assistance with the imagining densitometer.

Open Access This article is distributed under the terms of the Creative Commons Attribution Noncommercial License which permits any noncommercial use, distribution, and reproduction in any medium, provided the original author(s) and source are credited.

\section{References}

1. Raikos V, Hensen R, Campbell L, Euston SR (2006) Separation and identification of hen egg protein isoforms using SDS-PAGE and 2D gel electrophoresis with MALDI-TOF mass spectrometry. Food Chem 99:702-710

2. Mann K, Mann M (2008) The chicken egg yolk plasma and granule proteomes. Proteomics 8:178-191

3. Campbell L, Raikos V, Euston SR (2003) Modification of functional properties of egg white proteins. A review. Nahrung/Food 47:369-376

4. Kiosseoglou V (2003) Egg yolk protein gels and emulsions. Curr Option Colloid Interface Sci 8:365-370

5. Michalski WP (1996) Chroatographic and electrophoresis methods of superoxide dismutases. J Chromatogr B Biomed Apl 684:59-75

6. Bartosz G (2006) Druga twarz tlenu, Wolne rodniki w przyrodzie. Wydawnictwo Naukowe PWN SA, Warszawa, Poland, in polish

7. Zabłocka A, Janusz M (2008) Dwa oblicza wolnych rodników. Postęp Hig Med Dosw 62:118-124, in polish

8. Ziemlański Ś, Wartanowicz M (1995) Witaminy antyoksydacyjne. Nowa Med 2:7-12, in polish

9. Ziemlański Ś, Wartanowicz M (1999) Rola antyoksydantów żywieniowych w stanie zdrowia i choroby. Pediatria Współczesna Gastroenterol Hepatol Żywienie Dziecka, 1, (2/3):97-105, in polish

10. Yu BP (1994) Cellular defenses against damage from reactive oxygen species. Physiol Rev 1:139-162

11. Marklund SL, Holme E, Heller L (1982) Superoxide dismutase in extracellural fluids. Clin Chim Acta 126:41-51

12. Marklund SL, Bjelle A, Elmqvist LG (1986) Superoxide dismutase isoenzymes of the synovial fluid in rheumatoid arthritis and in reactive arthritides. Ann Rheum Dis 45:847-851

13. DiSilvestro RA, Yang FL, David EA (1992) Species-specific heterogeneity for molecular weight estimates of serum extracellural superoxide dismutase activities. Comp Biochem Physiol B 101:531-534

14. Youn HD, Kim EJ, Roe JH, Hah VC, Kank S (1996) A novel nickel-containing superoxide dismutase from Streptomyces spp. J Biochem 318:889-896

15. Aydemìr T, Tarhan L (2001) Purification and partial characterization of superoxide dismutase from chicken erythrocytes. Turk J Chem. 25:451-459

16. Schininå ME, Carlinie P, Polticelli F, Zappacosta F, Bossa F, Calabrese L (1996) Amino acid sequence of chicken $\mathrm{Cu}$, $\mathrm{Zn}$-containing superoxide dismutase and identification of glutathionyl addcts at exposed cysteine residues. Eur Jour Biochem 237:433-439

17. Lindsay DG, Astley SB (2002) European research on the functional effects of dietary antioxidants-EUROFEDA. Mol Asp Med 23:1-38

18. Li B, Chen F, Wang X, Ji B, Wu Y (2007) Isolation and identification of antioxidative peptides from porcine collagen hydrolysate by consecutive chromatography and electrospray ionization-mass spectrometry. Food Chem 102:1135-1143

19. Park EY, Murakami H, Mori T, Matsumura Y (2005) Effects of protein and peptide addition on lipid oxidation in powder model system. J Agric Food Chem 53:137-144

20. Miguel M, Aleixadre A (2006) Antihypertensive peptide derived from egg protein. J Nutr 136:1457-1460

21. Gibbs BF, Zougman A, Masse R, Mulligan C (2004) Production and characterization of bioactive peptides from soy hydrolysate and soy-fermented food. Food Res Int 37:123-131

22. Tsuge N, Eikawa Y, Noura Y, Yamamoto M, Sugisawa K (1991) Antioxidative activity of peptides prepared by enzymatic hydrolysis of egg-white albumin. J Agric Chem Soc Jpn 65:1635-1641

23. Graszkiewicz A, Żelazko M, Trziszka T, Polanowski A (2007) Antioxidative capacity of hydrolysates of hen egg proteins. Pol J Food Nutr Sci 57:195-199 
24. Sakanaka S, Tachibana Y, Ishihara N, Juneja IR (2004) Antioxidant activity of egg-yolk protein hydrolysates in linoleic acid oxidation system. Food Chem 86:99-103

25. Gornal AG, Bardawill CJ, David MM (1949) Determination of serum proteins by means of the biuret method reaction. J Biol Chem 177:751-766

26. Griffiths HR, Möller L, Bartosz G, Bast A, Bertoni-Freddari C, Collins A, Cooke M, Coolen S, Haenen G, Hoberg A, Loft S, Lunec J, Olinski R, Parry J, Pompella A, Poulsen H, Verhagen H, Astley SB (2002) Biomarkers. Mol Asp Med 23:101-208

27. Sun M, Zigman S (1978) Determination of superoxide dismutase in erythrocytes using the method of adrenalin autooxidation. Anal Biochem 90:81-89

28. De Pelichy LDG, Smith ET (1997) A study of the oxidation pathway of adrenaline by cyclic voltammetry: an undergraduate analytical chemistry laboratory exercise. Chem Educ 2:1-13

29. Laemmli UK (1970) Clevage of structural proteins during the assembly of the head of bacteriophage T4. Nature 227:680-685
30. Misra HP, Fridovich I (1977) Superoxide dismutase and peroxidase: a positive activity stain applicable to polyacrylamide gel electropherograms. Arch Biochem Biophys 183:511-515

31. Tukey JW (1959) A quick, compact, two-sample test to Duckworth's specifications. Technometrics 1:31-48

32. Yost FT, Fridovich I (1973) An iron-containing superoxide dismutase from Escherichia coli. J Biol Chem 248:4905-4908

33. Keele BB Jr, McCord JM, Fridovich I (1970) Superoxide dismutase from Escherichia coli B. J Biol Chem 245:6176-6181

34. Pinto AL, Hellinga HW, Caradonna JP (1997) Construction of a catalytically active iron superoxide dismutase by rational protein design. Proc Natl Acad Sci 94:5562-5567

35. Froman DP, Thurston RJ (1981) Chicken and turkey spermatozal superoxide dismutase: a compare study. Biol Reprod 25:193-200

36. Öztürk-Ürek R, Tarhan L (2001) Purification and characterization of superoxide dismutase from chicken liver. Comp Biochem Physiol B 128:205-221 